Сучасне формотворення засновано на співпраці вчених, інженерів, дизайнерів та митців й вибудовує нові предметні та віртуальні форми, відповідні запитам сучасності. Об'єкти архітектурно-дизайнерської та мистецької творчості сьогодні продовжують наукові дослідження й експерименти (біології, фізики, інформатики, кібернетики, досліджень штучного інтелекту, візуалізації інформації), втілюючи їх в аудіовізуальне технологічно- й/або електронно-сформоване середовище, доступне й для споглядання, а й для контактної взаємодії. Таке гібридне мистецтво виходить за межі жанровості, розмиваючи границі між живописом, скульптурою, інсталяцією, кіно, перфоменсом, й об'єднує науку, соціально-політичний контекст, поп-культурні пріоритети та синтезує всі можливі форми психо-емоційного впливу на людину, створюючи навколо нього психо-моторну систему масової комунікації 3 метою емоційно-тонізуючого або компенсаторно-реакреційного впливу. Тут з'являються нові напрямки: медійна архітектура, геопросторова розповідь, використання робототехніки та штучного життя.

\title{
Література:
}

1. Лексикон нонклассики. Художественно-эстетическая культура 20 в. / Под ред. В. В. Бычкова. М.: РОССПЭН, 2003. 608 с.

2. Пригорницька А. Дизайн: постмодерні формовияви. Українська академія мистецтва: дослідницькі та наук.-метод. Праці. - 2006. Вип. 13 - С. 211-219.

DOI https://doi.org/10.30525/978-9934-26-004-9-115

\section{КУЛЬТУРОЛОГІЧНИЙ ПІДХІД В ОСМИСЛЕННІ ДИЗАЙНУ}

\section{Сергеєва Н. В.}

кандидат мистецтвознавства, доцент, доиент кафедри дизайну

Черкаського державного технологічного університету м. Черкаси, Украӥна

Важко не погодитися, що останнім часом культурологічний підхід як напрям загальнонаукової методології набуває все більшого значення. Важливу роль він відіграв і в постановці проблематики дизайну в культурі, актуалізації дизайну як феномену культури. Це стало остаточно очевидним лише 3 другої половини XX-го століття і пов'язано з тим, що і 
сама культурологія $є$ відносно молодою наукою. ÏÏ самостійна історія розпочалася із запропонованого американським вченим Леслі Елвіном Уайтом терміну «culturology», який потрапив до поля зору широкого кола науковців після публікації збірок праць «Наука про культуру» (1949 р.), «Еволюція культури» (1959 р.), «Поняття культури» (1973 р.). Саме цей період характеризується розвитком і практичної проблематики дизайну. Глобально, в багатьох відношеннях дизайн починає визначати загальний стан світової культури. Щоб відобразити тогочасні тенденції осмислення культурологічної ролі дизайну, варто навести дефініції дослідника Л.Н. Безмоздіна, який окреслює дизайн як «специфічну творчу діяльність людини, пов'язану з науково-технічною революцією й масовим виробництвом промислових виробів» і зазначає, що «реально дизайн існує в сучасному світі в межах двох протилежних соціальних систем, що його буття опосередковано приналежністю до двох протиставлених культур» [1, с. 163]. Цими полярними системами вважалися різні сутності соціалістичної та капіталістичної типів культур, без врахування особливостей яких, на думку Л. Н. Безмоздіна, не можливо було б пізнати закономірності розвитку дизайну. Надалі, він пропонує більш ємне визначення дизайну - «особлива творча діяльність 3 проектування гармонізованих із людиною елементів предметного середовища та їх комплексів (включно з системною організацією під цим кутом всього предметного середовища в цілому), відповідних світу соціальних i культурних цінностей, які реалізовуються засобами сучасного промислового виробництва» [1, с. 164]. При цьому, він вказує, що дизайн $є$ орієнтованим на різноспрямовані параметри культури, а не лише на обрані за критеріями технічної та функціональної досконалості елементів матеріальної культури, i, опосередковано, через естетичну організацію всього предметного середовища $є$ пов'язаним із духовними й художніми складовими культури.

На неподільність єдності створеного людиною матеріального об'єкту і культури вказують й деякі інші сучасні дослідники. Так, І. О. Розенсон обгрунтовує здатність окремого одиничного екземпляру (речі) до представлення певного регіону або ж, навіть, цілої історичної епохи. На думку дослідниці, один і той самий об'єкт, вилучений з контексту свого культурного середовища, буде зберігати та доносити набагато більше, ніж просто формалізовані якості. Очевидним $є$ те, що річ в культурі виконує функцію матеріального носія стилю та характерних рис людської життєдіяльності. Так, річ не лише несе в собі образ самобутньої культури, котра іï породила, а й уміщує в себе всі ідеї та змісти, якими наділяється ця культура в свідомості людей у певний етап свого розвитку 
[4, с. 27-28]. Відповідно, щоб розірвати зв'язки людини 3 певною культурою та утворити нові, достатньо змінити ії речове оточення.

У якості такого прикладу можна навести дії радянської влади після Жовтневої революції 1917 року, коли найперше, що було зроблено - це нова символіка держави, зміна деяких елементів існуючого алфавіту, заміна пам'ятників старої влади на пам'ятники революціонерам й схильним до нової влади постатям, введення нової військової форми. Сюди ж можна віднести й яскраву творчість В. В. Маяковського 3 напрацювання лаконічної й зрозумілої «простому народу» манери віршування та графіки, кінетичні розробки В. С. Татліна тощо. Широко представлений у науковій літературі радянський період 20-х років XX століття є одним із всесвітньо визнаних фактів формування моделі нового предметного середовища, яку обумовлювала наявність певної ідеологічної концепції. Керівник Центру теорії й історії культури Інституту гуманітарних досліджень МГУ В. А. Луков пояснює, що все, що відбувалося у ці роки в радянському дизайні було пов'язане з певною заміною (символіки, оформлення міст, алфавіту, шрифтів, реклами, одягу, почесних звань, освіти і т.д.) і визначає особливу соціокультурну роль дизайну як функцію розмежування нового світу від старого. Також, В. А. Луков вказує на життєву необхідність такого розмежування, яке мало бути сприйнятим раніше змісту i саме стати знаком, щоб спрямовувати це сприйняття у необхідну сторону. За його висловлюванням, «для того, щоб зрозуміти нову доктрину, необхідні час та освіта. Для того, щоб зорієнтуватися, потрібні прості та яскраві (як знаки світлофору) дизайнерські рішення» [3, с. 43].

На думку сучасної дослідниці Т. Ю. Бистрової, речі не лише забезпечують різноманітні потреби, а й фіксують інформацію про тих, хто їх створює, забезпечуючи передачу досвіду життєдіяльності й сприяючи соціалізації кожного нового покоління. Потенційні можливості речі як продукту дизайну Т. Ю. Бистрова розглядає на прикладі конкретних функцій, які умовно розподіляє на дві групи: 1) функції речі, пов'язані 3 гармонізацією предметного світу засобами дизайну; 2) функції речі, які гармонізують буття людини в культурі. Так, до першої групи віднесено гуманізуючу, організуючу, раціоналізуючу, утворюючу, утопічну та екологічну функції. До другої групи функцій зараховано естетичну, сигніфікативну, соціалізуючу, спілкування, гедоністичну, актуалізуючу, знакову та ідеологічну функції [2].

В цілому ж, головною культурологічною інтерпретацією дизайну $\epsilon$ його віднесення до повсякденної (буденної) культури, в якій він починає набувати установку не на авторське самовираження чи на відповідність 
певним естетичним законам, а на обумовлені рівнем розвиненості смаку, характером очікувань й уподобань чи запитів тощо споживачів цієї повсякденної культури. Відтак, дизайн, підпадаючи під сферу іiі формування, стає дотичним вже до такого феноменального явища як мода.

В своєму найширшому тлумаченні мода позначає міру, еталон, норму, стандарт, спосіб, манеру, образ дій, форму, вид, властивість, якість, природу та виступає в ролі головного механізму, логіки чи ідеології. I, в першу чергу, за міркуваннями відомого філософа А. Сміта, мода властива тому, де основним є відчуття смаку. Так, будь яка мода це змінний спосіб життя (I. Кант); соціальний феномен, який проявляє себе у всіх сферах життя суспільства (Г. Зіммель); певна форма соціальних змін, яка не залежить від об'єкту і являє собою соціальний механізм, для якого характерна своєрідна короткочасність і певний ступінь мінливості, який впливає на найрізноманітніші сфери життя тих чи інших груп осіб (Ж. Ліповєцкі).

Тож, цілком підтримуючи наведені визначення погоджуємося, що мода може розглядатися як механізм чи ідеологія, котрі на практичному рівні діють у всіх можливих сферах сучасного світу й тісно пов'язані 3 поняттям смаку з одного боку та 3 поняттям «нового» з іншого. Відтак, можемо припустити, що в такому контексті мода стає дотичною до поняття концепції конкретної дизайнерської розробки чи дизайндіяльності в цілому. I з таких позицій розгляду, нам можуть бути вже цікавими принципи формування моди як своєрідного механізму впливу на формування смаку та естетики в дизайні.

\section{Література:}

1. Безмоздин Л. Н. Дизайн в современной культуре. Искусство в системе культуры. Л. : Наука, Ленингр. отд., 1987. С. 163-167.

2. Быстрова Т. Ю. Феномен вещи в дизайне: Философскокультурологический анализ : автореф. дис. ... докт. философ. наук : 09.00.13. Екатеренбург, 2003. 42 с.

3. Луков В. А. Дизайн: тезариусный анализ : науч. монография. М. : МГУ, 2007. $129 \mathrm{c.}$

4. Розенсон И.А. Основы теории дизайна : учебник для вузов. СПб.: Питер, 2008. 219 с. 